\title{
RÁDIO: RECURSO TECNOLÓGICO NO CONTEXTO EDUCATIVO NA TRANSMISSÃO DA
} HISTÓRIA LOCAL

\section{Amanda Marques Vieira*, Dayana de O. Formiga, Letícia Sponton Cândido, Thaís Caroline de Almeida Lima.}

\section{Resumo}

Esta pesquisa propõe apresentar e discutir com os alunos de uma escola da Região metropolitana de Campinas a valorização histórica da cidade no ambiente escolar, principalmente dentro do Ensino de História, juntamente com a iniciativa de um programa de rádio. A partir desse objetivo, pretende-se estimular nos discentes o conhecimento do local onde estão inseridos e propiciar mecanismos de abordagens pedagógicas que auxiliem em suas pesquisas e facilite seu aprendizado. Para isso, será utilizado referenciais bibliográficos que abordam como a rádio se tornou um veículo de comunicação de massa na divulgação da cultura brasileira, além das contribuições que seu uso possa apresentar no ambiente escolar. Expondo a trajetória histórica da cidade onde estão inseridos, a fim de possibilitar uma visão sobre a identidade do local. Com isso, o projeto pretende trazer uma reflexão com os discentes acerca da cultura da cidade, proporcionando sua participação ativa.

\section{Palavras-chave:}

História Local, Escola, Rádio.

\section{Introdução}

Esse estudo tem como objetivo analisar o uso do rádio como ferramenta pedagógica para as aulas de história, para que tanto alunos quanto a comunidade possam conhecer sua história local e, consequentemente, desenvolver sua identidade.

A invenção do rádio alcançou sucesso nas mídias em pouco tempo, visto que a necessidade de melhores instrumentos para comunicação se tornava cada vez mais crescente. Assim, segundo Ferreira (2012), tal ferramenta foi utilizada para diversos segmentos sociais, seja para guerra, propagação de informações, uso comercial, político ou educativo.

De acordo com Mansuco (2012), quando tal tecnologia chega no Brasil, o governo apropriasse dela como veículo de comunicação, utilizando como recurso de alfabetização do país. Com isso, entre 1950 e 1960, foram desenvolvidos programas de alfabetização, principalmente para as regiões Norte e Nordeste, como o MEB (Movimento de Educação Base) e o MOBRAL (Movimento Brasileiro de Alfabetização).

Objetivo da aprendizagem com o uso do rádio é a construção de conhecimentos, como cidadania, educação, meio ambiente e cultura. Diante disso, existe a necessidade da integração entre comunicação e educação, de forma que estejam presentes em uma nova proposta educativa, onde se busca a construção de novos valores, busca por conhecimento, compartilhamento de ideias e integração social (CHAGAS; SANTOS, 2010).

Diante disso, Chagas e Santos (2010) afirmam que a educação do século XXI tem o desafio de formar cidadãos que consigam transformar informações recebidas em conhecimento e benefícios para sua própria comunidade. Segundo Mancuso (2012), com esse processo o discente é colocado como protagonista de sua própria aprendizagem, podendo reconstruir seus conceitos e atitudes de maneira reflexiva.

\section{Resultados e Discussão}

Engenheiro Coelho, cidade onde está localizada a escola, foi sendo desenvolvida pela força de trabalho de imigrantes europeus e migrantes brasileiros, fato esse que ainda ocorre atualmente, o que dificulta os alunos a criar um senso de pertencimento ao local. Para tanto, foram aplicadas enquetes em quatros turmas de sétimo ano com perguntas referentes a rádio e a história da cidade, no intuito de conhecer o interesse dos alunos em relação ao projeto e ao município. Como também, um exercício rápido de produção de texto para que os alunos escrevessem o que sabiam sobre a história de Engenheiro Coelho, assim como observar o nível de conhecimento com relação à sua cidade, a fim de dar início ao desenvolvimento do projeto. Da mesma forma, houveram aulas expositivas acerca da história da cidade relacionando com 0 conteúdo didático abordando detalhes históricos envolvendo o nome da localidade, estimulando dessa maneira o interesse dos discentes pela história de seu município. Com isso, foram realizadas as gravações com os estudantes, nos quais liam pequenos textos para que suas vozes fossem transmitidas pela rádio.

\section{Conclusões}

O projeto funda-se na ideia de fazer com que os discentes possam conhecer mais a história de sua comunidade, criando um senso maior de identidade e de construção da história. Assim, estimulando a pesquisa histórica no desenvolvimento de seus trabalhos e dando continuidade a escrita de sua própria estória.

\section{Agradecimentos}

Agradecemos ao UNASP-EC e ao Programa Residência Pedagógica/ CAPES pela ajuda e financiamento desta pesquisa.

CHAGAS, A. B.; SANTOS, L. M. A. O rádio na educação: desenvolvendo habilidade em comunicação. 2010. 13 f. Monografia (Especialização) - Curso de Mídia em Educação, Universidade Federal de Santa Maria, Santa Maria, 2010. Disponível em: 〈https://bit.ly/2XcaCxz〉. Acesso em: 25 jan. 2019. FERREIRA, V. C. O uso do rádio no processo de ensino e aprendizagem. 2012. 44 f. Monografia (Especialização) - Curso de Especialização em Mídias na Educação, Universidade Federal do Amapá Unifap, Macapá, 2012. Disponível em: < https://bit.ly/322oxtk>. Acesso em: 16 jan. 2019.

MANCUSO, V. M. O uso do rádio no processo de ensinoaprendizagem. 2012. 49 f. Monografia (Especialização) - Curso de Mídias na Educação, Centro Interdisciplinar de Novas Tecnologias na Educação,

Universidade Federal do Rio Grande do Sul, Porto Alegre, 2012. Disponível em: <https://bit.ly/2JaTIu6>. Acesso em: 28 jan. 2019. 